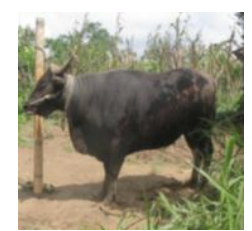

Jurmal FADET UNUD

\title{
PENGARUH PEMBERIAN KONSENTRAT TERHADAP KECERNAAN NUTRIEN PADA SAPI BALI INDUK PASCA MELAHIRKAN
}

\author{
Kristina, N. L. P., N. P. Mariani., dan T. I. Putri \\ PS Sarjana Peternakan, Fakultas Peternakan, Universitas Udayana, Denpasar, Bali \\ Email: niluhputukristina@student.unud.ac.id Telpon:+6281907177596
}

\begin{abstract}
ABSTRAK
Penelitian ini bertujuan untuk mengetahui level penambahan konsentrat yang mampu meningkatkan kecernaan nutrien ransum pada sapi bali induk pasca melahirkan. Penelitian dilaksanakan di Kelompok Ternak Sedana Bakti Pertiwi di Desa Kesiman, Denpasar Timur selama tiga bulan, menggunakan 12 ekor sapi bali induk pasca melahirkan. Analisis sampel ransum dan feses dilaksanakan di Laboratorium Nutrisi dan Makanan Ternak Fakultas Peternakan Universitas Udayana selama satu bulan. Rancangan percobaan yang digunakan adalah rancangan acak kelompok (RAK) dengan tiga perlakuan dan empat kelompok sebagai ulangan. Perlakuan tersebut adalah hijauan (rumput gajah, rumput lapangan, batang jagung dan kulit jagung) ad lib (P0), 0,5kg konsentrat + hijauan ad lib (P1), dan $1 \mathrm{~kg}$ konsentrat + hijauan ad lib (P2). Variabel yang diamati meliputi kecernaan bahan kering (KCBK), kecernaan bahan organik (KCBO), kecernaan protein kasar (KCPK), dan kecernaan serat kasar (KCSK). Hasil penelitian menunjukkan semakin tinggi penambahan konsentrat pada ransum, maka semakin meningkat pula kecernaan bahan kering dan kecernaan bahan organik sapi, dengan nilai masing-masing 63,73\% -71,18\% dan 88,45\%-74,70\% secara statistik menunjukkan perbedaan yang nyata $(\mathrm{P}<0,05)$. Kecernaan protein kasar dan kecernaan serat kasar semakin meningkat dengan nilai masingmasing 66,88\%-73,32\% dan 74,70\%-77,45\% namun secara statistik menunjukkan perbedaan tidak nyata $(\mathrm{P}>0,05)$. Berdasarkan hasil penelitian dapat disimpulkan bahwa pemberian ransum dengan level konsentrat $0,5 \mathrm{~kg}$ dan $1 \mathrm{~kg}$ belum mampu meningkatkan kecernaan nutrien ransum secara maksimal.
\end{abstract}

Kata kunci: konsentrat, kecernaan nutrien, sapi bali induk pasca melahirkan

\section{THE EFFECT OF CONCENTRATE PROVISION ON NUTRIENT DIGESTIBILITY OF POST-PARTUM BALI COWS}

\begin{abstract}
This study aims to determine the level of addition of concentrate that is able to improve the digestibility of nutrient ration in post-partum bali cow. This research was conducted at the Sedana Bakti Pertiwi Livestock Group in Kesiman Village, East Denpasar for three months, used 12 post-partum bali cows. Analysis of ration and feces samples was carried out at the Animal Nutrition and Feed Laboratory of the Faculty of Animal Husbandry, Udayana University for one month. The experimental design used was a randomized block
\end{abstract}


design (RBD) with three treatments and four replications. The treatments were ad lib forage (elephant grass, field grass, corn stalks and corn husk) (P0), $0.5 \mathrm{~kg}$ concentrate + given ad lib forage $(\mathrm{P} 1), 1 \mathrm{~kg}$ concentrate + given ad lib forage (P2). Variables observed included dry matter digestibility, organic matter digestibility, crude protein digestibility, and crude fiber digestibility. The results showed that the higher the addition of concentrate in the ration, the higher the digestibility of dry matter and the highest digestibility of organic cow, with values of $63.73 \%-71.18 \%$ and $88.45 \%-74.70 \%$ respectively statistically showed a significant difference $(\mathrm{P}<0.05)$. While the digestibility of crude protein and crude fiber digestibility increased with values of $66.88 \%-73.32 \%$ and $74.70 \%-77.45 \%$ respectively but statistically the results showed no significant difference $(\mathrm{P}>0.05)$. Based on the results of the study it can be concluded that the provision of rations with concentrations of $0.5 \mathrm{~kg}$ and $1 \mathrm{~kg}$ have not been able to increase the digestibility of nutrient ration maximally.

Keywords: concentrate, nutrient digestibility, post-partum bali cow

\section{PENDAHULUAN}

\section{Latar Belakang}

Sapi bali merupakan salah satu plasma nutfah asli Indonesia yang berpotensi sebagai ternak potong dan mempunyai prospek pemasaran yang baik untuk pemenuhan kebutuhan daging nasional. Sapi bali dapat memasok kebutuhan daging sekitar $26 \%$ dari total sapi potong di Indonesia (Guntoro, 2006). Produktivitas sapi lokal di Indonesia relatif rendah, mengingat sebagian besar peternak di Indonesia masih menggunakan sistem pemeliharaan secara tradisional dengan pemberian pakan seadanya (Muladno, 2012). Winugroho et al. (2007) melaporkan bahwa seekor ternak yang mendapat pakan dalam jumlah yang tidak memenuhi kebutuhan akan menyebabkan cekaman dan terjadinya penurunan bobot hidup ternak yang bersangkutan.

Manajemen pakan memiliki proporsi sebesar tujuh puluh persen dalam produktivitas susu untuk pedet, dan sisanya adalah breeding dan manajemen kandang (Hartutik 2009). Maryono (2006) menyatakan pemeliharaan sapi bali di tingkat peternak umumnya masih bersifat tradisional. Hal ini terlihat dari pakan yang diberikan masih mengandalkan hijauan (rumput-rumputan) tanpa memperhatikan kandungan nutrien dari pakan tersebut, walaupun terdapat peternak yang memberi pakan dengan tambahan dedak padi, namun dari segi kecukupan dan keseimbangan nutriennya masih belum tercukupi dan menjamin pencapaian produktivitas yang optimal. Pemberian pakan berupa hijauan (rumput-rumputan) memiliki nilai cerna yang relatif rendah akibat serat kasar tinggi, sehingga tidak mampu memenuhi kebutuhan nutrien dan akan berdampak terhadap pertumbuhan dan produksi ternak. 
Perbaikan pakan dengan penambahan konsentrat pada sapi induk setelah melahirkan dapat meningkatkan produksi susu untuk kebutuhan pedet (Umiyasih et al., 2007). Proporsi kandungan konsentrat dalam ransum dapat meningkatkan intake pakan, kadar protein susu, dan bobot badan (Sanh et al., 2002). Sapi induk setelah melahirkan secara fisiologis akan menyalurkan energi tubuh untuk memproduksi susu, sehingga badannya menyusut. Pemberian pakan dengan kualitas yang lebih tinggi akan menghasilkan penampilan yang lebih baik karena dapat meningkatkan konsumsi jumlah pakan (Mukminah et al., 2011).

Ternak ruminansia mempunyai keterbatasan dalam mengkonsumsi pakan hijauan yang tumbuh di daerah tropis karena kandungan gizinya relatif rendah, oleh karena itu dalam peningkatan produktivitas sapi bali perlu diberikan pakan tambahan berupa konsentrat, yang banyak mengandung karbohidrat, protein, serat kasar serta berbagai mineral. Penambahan mutu pakan dengan perbandingan hijauan dan konsentrat yang seimbang akan memberikan tampilan produksi dan kadar lemak susu yang bagus (Setyaningsih et al., 2013). Konsentrat adalah bahan makanan yang konsentrasi gizinya tinggi tetapi kandungan serat kasarnya relatif lebih rendah dan mudah dicerna (Priyono, 2008).

Berdasarkan hasil penelitian Koddang (2008), sapi bali jantan yang diberikan konsentrat 2,0\% dari bobot badan mampu meningkatkan daya cerna serat kasar hingga $64,11 \%$ dan daya cerna protein hingga $74,66 \%$. Upeksa et al. (2016) menyatakan pada sapi bali bunting 7 bulan yang diberi tambahan $43 \%$ konsentrat pada ransum mendapatkan hasil kecernaan bahan kering 58,86\%, kecernaan bahan organik 59,69\%, kecernaan serat kasar $55,10 \%$, kecernaan protein kasar sapi 66,09\%. Hasil penelitian Valentina et al. (2018), sapi bali dara yang diberi tambahan $35 \%$ konsentrat pada ransum mendapatkan kecernaan bahan kering 71,17\%, kecernaan bahan organik 72,60\%, kecernaan protein kasar 76,42\%, kecernaan serat kasar 53,13\%.

Berdasarkan uraian tersebut, maka perlu dilakukan penelitian untuk mengetahui kecernaan ransum pada sapi bali induk pasca melahirkan yang diberikan tambahan konsentrat. 


\section{MATERI DAN METODE}

\section{Sapi bali}

Sapi bali yang digunakan dalam penelitian ini adalah sapi bali induk pasca melahirkan, dengan kriteria induk yang telah melahirkan satu minggu sampai dengan delapan bulan dan beranak 1- 4 kali. Sapi bali induk yang digunakan sebanyak 12 ekor.

\section{Kandang dan peralatannya}

Kandang yang digunakan merupakan kandang individu berjumlah 12 petak dengan memiliki ukuran panjang panjang $\times$ lebar $=200 \mathrm{~cm} \times 150 \mathrm{~cm}$ yang dilengkapi dengan tempat pakan dan minum. Kemiringan lantai kandang adalah $5^{\mathrm{O}}$ berfungsi mempermudah mengalirnya urin dan kotoran yang dikeluarkan oleh ternak menuju selokan pembuangan kotoran. Kontruksi atap kandang terbuat dari seng, sementara lantai kandang dan tempat pakan terbuat dari beton. Ukuran tempat pakan $50 \mathrm{~cm} \times 100 \mathrm{~cm}$.

\section{Ransum dan air minum}

Ransum yang diberikan terdiri atas hijaun (rumput gajah, rumput lapangan, batang tanaman jagung dan kulit jagung) sesuai dengan hijaun yang diberikan oleh peternak di lapangan sebagai pakan dasar dan konsentrat Lactoplus merk Nuufeed, dengan kandungan protein 16\%, lemak kasar 7\%, serat kasar 12\%, NDF 35\%, air 12\%, TDN 70\%, kalsium 1\%, fosfor $0,8 \%$, aflatoxin $200 \mathrm{ppb}$ sebagai pakan tambahan. Air minum yang diberikan bersumber dari PDAM yang terdapat pada lokasi penelitian.

Tabel 1. Kandungan nutrien pakan hijauan dan konsentrat yang diberikan pada sapi bali induk pasca melahirkan

\begin{tabular}{lccccccc}
\hline \multicolumn{1}{c}{ Bahan Pakan(\%) } & DM & PK & ABU & BO & SK & LK & TDN \\
\hline Rumput Gajah & 90,51 & 7,93 & 13,75 & 76,93 & 28,41 & 10,01 & 25,51 \\
Rumputlapangan & 92,25 & 10,15 & 11,76 & 80,5 & 33,59 & 7,53 & 11,33 \\
Pohon jagung & 90,30 & 10,27 & 9,19 & 81,1 & 23,25 & 6,65 & 33,1 \\
Kulit jagung & 92,21 & 12,09 & 6,9 & 85,31 & 32,68 & 8,03 & 13,89 \\
Konsentrat & 91,96 & 17,87 & 9,21 & 82,75 & 19,39 & 16,07 & 52,13 \\
\hline
\end{tabular}

Hasil analisis Laboratorium Nutrisi dan Makanan Ternak, Fakultas Peternakan Universitas Udayana (Mariani et al., 2019) 


\section{Alat-alat penelitian}

Alat-alat yang digunakan dalam penelitian ini, terdiri dari:

1. Alat-alat yang digunakan dilapangan terdiri atas: ember sebagai tempat menampung feses, cepang sebagai alat pengambilan feses, kantong plastik sebagai tempat sampel feses, timbangan kapasitas 50kg dengan kepekaan $10 \mathrm{~g}$ untuk menimbang sampel feses, timbangan analitik kapasitas 200g dengan kepekaan 0,1 mg untuk menimbang sampel feses, tray aluminium sebagai wadah tempat sampel feses, plastik klip ukuran $15 \mathrm{~cm} \mathrm{x}$ $10 \mathrm{~cm}$ sebagai tempat sampel feses.

2. Alat-alat yang digunakan di laboratorium terdiri atas: cawan porselin, oven (thermologic), desikator, tanur listrik dengan suhu $500^{\circ} \mathrm{C}$, mortal dan pastle, labu Kjeldahl, destilator ICW (Ivan, Clack, and White), Sand Bath untuk analisis serat kasar, kertas saring.

3. Zat kimia untuk analisis protein kasar dan serat kasar terdiri dari: $\mathrm{H}_{2} \mathrm{SO}_{4}$ pekat, $\mathrm{NaOH}$ $50 \%$, Asam borak 2\%, indikator campuran (20ml BCG 0,1\%+4ml MR 0,1\% dalam alkohol), HCl, 1 tablet katalis (1g Sodium Sulfat Anhydrous + 10mg Se), butiran gelas, $\mathrm{H}_{2} \mathrm{SO}_{4} 1,25 \%$, aquades, $\mathrm{NaOH} 1,25 \%$, Ethanol, Aseton.

\section{Tempat dan lama penelitian}

Penelitian lapangan dilaksanakan di Kelompok Ternak Sedana Bakti Pertiwi di Desa Kesiman, Denpasar Timur. Untuk analisis kandungan nutrien pakan dilaksanakan di Laboratorium Nutrisi dan Makanan Ternak Fakultas Peternakan, Universitas Udayana. Seluruh rangkaian penelitian dari masa pemeliharaan ternak sapi sampai analisis sampel pakan di laboratorium dilaksanakan selama \pm 4 bulan (Juni - September 2019).

\section{Pengelompokan ternak}

Sebelum percobaan dimulai, sapi yang digunakan ditimbang terlebih dahulu untuk mengetahui bobot badan awal dari masing-masing ternak. Selanjutnya dilakukan pengelompokan, bobot badan yang mendekati dikumpulkan dalam satu kelompok. Setiap kelompok terdiri dari tiga ekor sapi dengan bobot badan yang hampir sama. Demikian seterusnya hingga didapatkan empat kelompok ternak dengan bobot badan awal pada masing-masing kelompok berbeda. Setiap kelompok mendapatkan semua perlakuan, dan ternak dalam kelompok diacak untuk mendapatkan perlakuan tersebut.

\section{Pemberian ransum dan air minum}

Pemberian ransum dilakukan dua tahap yaitu pagi pukul 08.00 WITA diberikan konsentrat sesuai perlakuan kemudian setelah itu diberikan pakan hijauan dan pukul 15.00 WITA diberikan pakan hijauan. Pakan hijauan (rumput gajah, rumput lapangan, batang jagung dan kulit jagung) sesuai porsi yang diberikan oleh peternak dilapangan dan air minum diberikan ad libitum. 


\section{Rancangan penelitian}

Rancangan percobaan yang digunakan adalah Rancangan Acak Kelompok (RAK) yang terdiri dari tiga perlakuan dan empat kelompok sebagai ulangan, sehingga terdapat 12 unit percobaan. Adapun perlakuannya adalah:

$\mathrm{P}_{0}$ : sapi yang diberikan pakan hijauan $a d$ lib

$\mathrm{P}_{1}: 0,5 \mathrm{~kg}$ konsentrat + hijauan ad lib

$\mathrm{P}_{2}: 1 \mathrm{~kg}$ konsentrat + hijauan ad lib

\section{Penelitian lapangan}

Pengukuran kecernan dilakukan dengan metode koleksi total. Koleksi total dilaksanakan pada akhir penelitian yaitu selama tujuh hari secara berturut- turut. Pengambilan sampel feses dilakukan setiap hari selama koleksi total dengan mengambil sebanyak 200g sampel feses segar, kemudian dikeringkan dibawah sinar matahari. Sampel feses yang diperoleh selama koleksi total digabung sesuai perlakuan, kemudian diambil sub sampel sebanyak 200g untuk dianalisis di laboratorium.

Pengambilan sampel pakan hijauan dilakukan sekali selama koleksi total, dengan mengambil sebanyak $1 \mathrm{~kg}$ hijauan (rumput gajah, rumput lapangan, batang jagung, dan kulit jagung) sesuai yang diberikan oleh peternak dilapangan, selanjutnya hijauan tersebut dikeringkan dibawah sinar matahari, setelah kering sampel hijauan ditimbang untuk mendapatkan berat kering matahari. Jika terdapat sisa pakan hijauan pada tempat pakan, maka sisa hijauan tersebut ditimbang dan kemudian dikeringkan, setelah tujuh hari sisa pakan dikomposit dan diambil sub sampel sebanyak 200g. Sampel pakan hijauan dianalisis proksimat yang meliputi bahan kering (BK), bahan organik (BO), protein kasar (PK), dan serat kasar (SK), sedangkan sampel sisa pakan hanya dilakukan analisis bahan kering (BK) saja.

\section{Penelitian laboratorium}

\section{Penentuan bahan kering}

Cara menentukan bahan kering feses dan sampel pakan hijauan adalah sebagai berikut:

Kadar bahan kering dihitung dengan rumus:

Bahan kering $(\%)=\mathrm{WS}-\mathrm{W} \times 100 \%$

Keterangan:

$\mathrm{WS}=$ Berat cawan berisi sampel setelah di oven $(\mathrm{g})$

$\mathrm{W}=$ Berat konstan cawan kosong $(\mathrm{g})$

$\mathrm{S} \quad=$ Berat sampel $(\mathrm{g})$ 
Konsumsi bahan kering $(\mathrm{BK})=$ jumlah ransum yang diberikan $\mathrm{x} \% \mathrm{BK}$ ransum - sisa ransum $\mathrm{x}$ $\%$ BK sisa

\section{Penentuan bahan organik}

Kandungan bahan organik feses dan sampel pakan hijauan ditentukan dengan mempergunakan metode AOAC (2005).

Kadar abu $(\%)=\frac{\text { berat abu }}{\text { berat sampel }} \times 100 \%$

Kadar Bahan Organik (\%) = $100-$ kadar abu (\%DM basis)

Konsumsi bahan organik $(\mathrm{BO})=$ jumlah konsumsi ransum $(\mathrm{BK}) \mathrm{x} \% \mathrm{BO}$ ransum

\section{Penentuan protein kasar}

Kadar protein kasar pada feses dan sampel paka hijauan ditentukan dengan metode semi mikro "Kjeldahl" yang terbagi atas tiga fase yaitu:fase destruksi, fase destilasi, fase titrasi

Kadar protein kasar $(\%)=a(b-c) \times 14 \times 6,25 \times 100 \%$

\section{$\mathrm{S}$}

Keterangan:

a $\quad=$ Normalitas titrator $(\mathrm{HCL})(\mathrm{N})$

$\mathrm{b} \quad=$ Volume HCL untuk titrasi sampel $(\mathrm{ml})$

c $\quad=$ Volume HCL untuk titrasi blanko $(\mathrm{ml})$

$14=$ Ekuivalensi nitrogen $(\mathrm{mg})$

$6,25=$ Faktor protein

$\mathrm{S} \quad=$ Berat sampel $(\mathrm{mg})$

Konsumsi protein kasar $(\mathrm{PK})=$ Jumlah konsumsi ransum $(\mathrm{BK}) \mathrm{x} \% \mathrm{PK}$ ransum

\section{Penentuan serat kasar}

Cara penentuan serat kasar feses dan sampel pakan hijauan adalah berat abu residu sampel $(\mathrm{ARS})=($ Berat cawan $+\mathrm{abu})-$ berat cawan. Kadar serat kasar dihitung dengan rumus:

Kadar serat kasar $(\%)=\mathrm{RS}-\mathrm{ARS} \times 100 \%$

$$
\mathrm{S}
$$

Keterangan:

$\mathrm{RS} \quad=$ Berat residu sampel $(\mathrm{g})$

ARS = Berat abu residu sampel $(\mathrm{g})$

$\mathrm{S} \quad=$ Berat sampel awal $(\mathrm{g})$

Kadar serat kasar sampel dihitung berdasarkan kadar bahan kering yang dilaksanakan melalui teknik konversi data.

Konsumsi serat kasar $(\mathrm{SK})=$ jumlah konsumsi ransum $(\mathrm{BK}) \mathrm{x} \% \mathrm{SK}$ ransum 


\section{Peubah yang diamati}

Peubah yang diamati dalam kecernaan nutrien yaitu:

\section{Kecernaan bahan kering (KCBK)}

$\operatorname{KCBK}(\%)=\mathrm{A}-\mathrm{B} \times 100 \%$

A

Keterangan: $\quad A=$ Bahan kering yang dikonsumsi $(\mathrm{g} / \mathrm{e} / \mathrm{h})$

$\mathrm{B}=$ Bahan kering feses $(\mathrm{g} / \mathrm{e} / \mathrm{h})$

\section{Kecernaan bahan organik (KCBO)}

$\operatorname{KCBO}(\%)=\underline{A}-\mathrm{B} \times 100 \%$

A

Keterangan: $\quad \mathrm{A}=$ Bahan organik yang dikonsumsi $(\mathrm{g} / \mathrm{e} / \mathrm{h})$

$\mathrm{B}=$ Bahan organik feses $(\mathrm{g} / \mathrm{e} / \mathrm{h})$

\section{Kecernaan protein kasar (KCPK)}

$\operatorname{KCPK}(\%)=\underline{A-B} \times 100 \%$

A

Keterangan: $\quad A=$ Protein kasar yang di konsumsi $(\mathrm{g} / \mathrm{e} / \mathrm{h})$

$\mathrm{B}=$ Protein kasar feses $(\mathrm{g} / \mathrm{e} / \mathrm{h})$

\section{Kecernaan serat kasar (KCSK)}

$\operatorname{KCSK}(\%)=\underline{A-B} \times 100 \%$

A

Keterangan: $\quad \mathrm{A}=$ Serat kasar yang dikonsumsi $(\mathrm{g} / \mathrm{e} / \mathrm{h})$

$\mathrm{B}=$ Serat kasar feses $(\mathrm{g} / \mathrm{e} / \mathrm{h})$

\section{Analisis statistik}

Data yang diperoleh dari hasil penelitian dianalisis dengan sidik ragam. Apabila terdapat hasil yang berbeda nyata $(\mathrm{P}<0,05)$ maka dilanjutkan dengan uji jarak berganda Duncan pada taraf $5 \%$ (Steel dan Torrie, 1993).

\section{HASIL DAN PEMBAHASAN}

Rataan hasil penelitian menunjukkan kecernaan nutrien sapi bali induk pasca melahirkan yang diberikan penambahan konsentrat P1 dan P2 cenderung mengalami peningkatan (Tabel 2). 
Tabel 2. Rataan kecernaan nutrien pada sapi bali induk pasca melahirkan

\begin{tabular}{lcccc}
\hline \multirow{2}{*}{ Variabel (\%) } & \multicolumn{3}{c}{ Perlakuan $^{1)}$} & SEM $^{2)}$ \\
\cline { 2 - 4 } & & P0 & P1 & P2 \\
\hline Kecernaan bahan kering(KCBK) & $63,73^{\text {b3) }}$ & $68,62^{\text {ab }}$ & $71,18^{\mathrm{a}}$ & 1,64 \\
Kecernaanbahanorganik(KCBO) & $68,45^{\mathrm{b}}$ & $73,01^{\mathrm{ab}}$ & $74,70^{\mathrm{a}}$ & 1,56 \\
Kecernaan protein kasar (KCPK) & $66,88^{\mathrm{a}}$ & $67,42^{\mathrm{a}}$ & $73,32^{\mathrm{a}}$ & 2,21 \\
Kecernaan serat kasar (KCSK) & $74,70^{\mathrm{a}}$ & $75,05^{\mathrm{a}}$ & $77,45^{\mathrm{a}}$ & 1,92
\end{tabular}

Keterangan:

1. Perlakuan

P0: sapi yang diberikan pakan hijauan ad lib

P1: 0,5kg konsentrat + hijauan ad lib

P2: $1 \mathrm{~kg}$ konsentrat + hijauan ad lib

2. SEM (Standart Error of the Treatment Means)

3. Superskrip yang berbeda pada baris yang sama menunjukkan berbeda nyata $(\mathrm{P}<0,05)$

Kecernaan nutrien pakan sangat dipengaruhi oleh kualitas dari pakan, kondisi lingkungan rumen, populasi dan aktivitas mikroba rumen. Kemampuan pakan untuk menyediakan nutrien bagi ternak ditentukan melalui analisis kimiawi, namun nilai sebenarnya akan ditunjukkan dengan bagian yang hilang setelah pencernaan, penyerapan dan metabolisme (Mc Donald et al., 2002). Hasil analisis sidik ragam menunjukkan bahwa tingkat pemberian konsentrat berpengaruh nyata $(\mathrm{P}<0,05)$ terhadap kecernaan bahan kering dan kecernaan bahan organik sedangkan berpengaruh tidak nyata $(\mathrm{P}>0,05)$ terhadap kecernaan protein kasar dan kecernaan serat kasar.

Kecernaan bahan kering pada sapi perlakuan P0 (hijauan ad lib) adalah 63,73\% (Tabel 2). Kecernaan bahan kering pada sapi perlakuan P1 (hijauan ad lib $+0,5 \mathrm{~kg}$ konsentrat) lebih tinggi 7,67\% dibandingkan P0, namun secara statistik berbeda tidak nyata $(\mathrm{P}>0,05)$. Kecernaan bahan kering pada sapi perlakuan P2 (hijauan ad lib $+1,0 \mathrm{~kg}$ konsentrat) lebih tinggi $11,69 \%$ dibandingkan $\mathrm{P} 0$, secara statistik berbeda nyata $(\mathrm{P}<0,05)$. Kecernaan bahan kering pada sapi bali induk pasca melahirkan yang mendapatkan perlakuan P2 berbeda nyata, hal ini disebabkan karena meningkatnya jumlah konsumsi bahan kering pada ternak, konsumsi bahan kering erat kaitannya dengan kecernaan, semakin meningkatnya konsumsi bahan kering maka akan diikuti dengan meningkatnya kecernaan bahan kering. Ditegaskan oleh Prasetiyono et al. (2007) peningkatan kecernaan nutrien pada ternak menyebabkan meningkatnya konsumsi ransum, sehingga proses pengosongan isi rumen berlangsung lebih cepat. Kecernaan bahan kering pada sapi perlakuan P2 sejalan dengan hasil penelitian Valentina et al. (2018) pada sapi bali dara yang diberikan tambahan 35\% konsentrat pada 
ransum hasil kecernaan bahan kering 71,17\%, lebih tinggi dari penelitian Upeksa et al. (2016) pada sapi bali bunting 7 bulan yang diberi tambahan $43 \%$ konsentrat pada ransum kecernaan bahan kering 58,86\%. Perbedaan ini disebabkan oleh status fisiologis ternak dan jumlah makanan, dan konsumsi bahan kering. Kecernaan bahan kering pakan juga sangat berhubungan dengan konsumsi, artinya: semakin tinggi nilai kecernaan suatu bahan pakan, ada kecendrungan konsumsi semakin banyak atau sebaliknya, pakan dengan nilai cerna rendah kecendrungan konsumsinya lebih rendah (Sudirman, 2013). Tillman et al. (1998) dan Anggorodi (1994) menyatakan faktor-faktor yang mempengaruhi nilai kecernaan ransum adalah tingkat proporsi bahan pakan dalam ransum, komposisi kimia, tingkat protein ransum, persentase lemak dan mineral. Dalam penelitian ini faktor yang mempengaruhi adalah tingkat proporsi antara hijauan dan konsentrat dalam ransum.

Kecernaan bahan organik pada sapi perlakuan P0 adalah 68,45\% (Tabel 2). Kecernaan bahan organik pada perlakuan sapi P1 lebih tinggi 6,66\% dibandingkan P0, namun secara statistik berbeda tidak nyata $(\mathrm{P}>0,05)$. Kecernaan bahan organik sapi perlakuan $\mathrm{P} 2$ lebih tinggi 9,14\% dibandingkan $\mathrm{P} 0$, secara statistik berbeda nyata $(\mathrm{P}<0,05)$. Kecernaan bahan organik sapi bali induk pasca melahirkan yang mendapatkan perlakuan P2 menunjukkan berbeda nyata $(\mathrm{P}<0,05)$. Peningkatan kecernaan bahan organik ini disebabkan karena meningkatnya kecernaan bahan kering, sebab secara proporsional laju keluarnya bahan kering selalu diikuti oleh keluarnya bahan organik, sehingga dengan semakin meningkatnya kecernaan bahan kering akan meningkatkan kecernaan bahan organik. Kecernaan bahan organik sapi perlakuan P2 lebih tinggi dibandingkan penelitian Upeksa et al. (2016) pada sapi bali bunting 7 bulan yang diberi tambahan $43 \%$ konsentrat pada ransum dan penelitian Valentina et al. (2018) pada sapi bali dara yang diberikan tambahan 35\% konsentrat pada ransum, mendapatkan hasil kecernaan bahan organik berturut-turut 59,69\% dan 72,60\%. Ismail (2011) menyatakan bahwa kecernaan bahan organik erat kaitannya dengan kecernaan bahan kering, karena sebagian dari BK terdiri dari bahan organik, sehingga penurunan kecernaan bahan kering akan mengakibatkan kecernaan bahan organik menurun atau sebaliknya. Sesuai yang dilaporkan Tillman et al. (1998) bahwa bahan organik merupakan komponen dari bahan kering, sehingga jika koefisien cerna bahan kering meningkat maka koefisien cerna bahan organik meningkat pula. Peningkatan kecernaan bahan organik ini disebabkan karena meningkatnya kecernaan bahan kering, sebab secara proporsional laju keluarnya bahan kering selalu diikuti oleh keluarnya bahan organik, sehingga dengan semakin meningkatnya kecernaan bahan kering akan meningkatkan kecernaan bahan organik. 
Kecernaan protein kasar ada sapi perlakuan P0 adalah 66,88\% (Tabel 2). Sapi yang mendapat perlakuan P1 dan P2 kecernaan protein kasar lebih tinggi berturut-turut 0,80\% dan 9,62\% dibandingkan dengan perlakuan P0, namun secara statistik berbeda tidak nyata $(\mathrm{P}>0,05)$. Kecernaan protein kasar sapi bali induk pasca melahirkan pada ketiga perlakuan menunjukkan perbedaan tidak nyata $(\mathrm{P}>0,05)$. Namun Kecernaan protein kasar menunjukkan hasil yang meningkat disetiap perlakuannya. Hal ini dikarenakan konsentrat merupakan sumber protein mudah terlarut yang mudah dirombak oleh mikrobia dalam rumen melalui proses fermentatif untuk menghasilkan sumber nitrogen rumen degradable protein (RDP) dalam rumen dan menunjang proses sintesis protein oleh mikroba, sehingga konsumsi protein kasar meningkat yang diiringi dengan meningkat pula kecernaan protein kasar. Simon et al. (2011) menyatakan bahwa peningkatan jumlah konsentrat di dalam ransum cenderung meningkatkan kandungan $\mathrm{NH} 3$ rumen, sehingga ketersediaan $\mathrm{N}$ cukup untuk mendukung pertumbuhan mikroba rumen yang berfungsi sebagai sumber protein bagi ternak. Kecernaan protein kasar sapi perlakuan P2 lebih rendah dibandingkan dengan penelitian Valentina et al. (2018) pada sapi bali dara yang diberikan tambahan 35\% konsentrat pada ransum mendapatkan hasil kecernaan protein kasar 76,42\%. Selanjutnya kecernaan protein kasar pada sapi perlakuan P2 lebih tinggi dibandingkan dengan penelitian Upeksa et al. (2016) pada sapi bali bunting 7 bulan yang diberi tambahan $43 \%$ konsentrat pada ransum mendapatkan kecernaan bahan kering 66,09\%. Hal ini didukung oleh Kettellars et al. (1992) yang menyatakan bahwa pemberian protein kasar yang tinggi pada pakan konsentrat mampu mengaktifkan mikroba rumen yang akan meningkatkan jumlah protein dan naiknya deaminasi yang mengakibatkan meningkatkan nilai kecernaan. Tillman et al. (1998) menyatakan bahwa faktor-faktor yang mempengaruhi kecernaan protein kasar adalah komposisi pakan, penyiapan pakan, faktor ternak dan jumlah konsumsi pakan.

Kecernaan serat kasar pada sapi perlakuan P0 adalah 74,70\% (Tabel 2). Sapi yang mendapat perlakuan P1 dan P2 kecernaan serat kasar lebih tinggi berturut-turut $0,47 \%$ dan 3,20\% dibandingkan dengan perlakuan $\mathrm{P} 0$, namun secara statistik berbeda tidak nyata $(\mathrm{P}>0,05)$. Kecernaan serat kasar sapi bali induk pasca melahirkan pada ketiga perlakuan menunjukkan perbedaan tidak nyata $(\mathrm{P}>0,05)$. Namun kecernaan serat kasar menunjukkan hasil yang meningkat pada setiap perlakuannya. Hal ini disebabkan karena pemberian konsentrat sebelum pemberian hijauan membuat mikroba rumen telah siap untuk mencerna partikel serat kasar dari hijauan, sehingga konsumsi serat kasar menjadi meningkat yang diiringi oleh peningkatan kecernaan serat kasar. Kecernaan serat kasar sapi perlakuan P2 lebih 
tinggi dibandingkan dengan penelitian Valentina et al. (2018) pada sapi bali dara yang diberikan tambahan 35\% konsentrat pada ransum dan penelitian Upeksa et al. (2016) pada sapi bali bunting 7 bulan yang diberi tambahan $43 \%$ konsentrat pada ransum, mendapatkan hasil kecernaan serat kasar berturut-turut 53,13\% dan 55,10\%. Serat kasar bagi ruminansia digunakan sebagai sumber energi utama, sehingga perlu diketahui kecernaannya dalam tubuh ternak. Menurut Despal (2000), serat kasar memiliki hubungan yang negatif dengan kecernaan. Semakin rendah serat kasar maka semakin tinggi kecernaan ransum. Tillman et al. (1998) menyatakan bahwa kecernaan serat kasar tergantung pada kandungan serat kasar dalam ransum dan jumlah serat kasar yang dikonsumsi. Kadar serat kasar terlalu tinggi dapat mengganggu pencernaan zat lain. Daya cerna serat kasar dipengaruhi oleh beberapa faktor antara lain kadar serat dalam pakan, komposisi penyusun serat kasar dan aktivitas mikroorganisme (Maynard et al., 2005).

\section{SIMPULAN DAN SARAN}

\section{Kesimpulan}

Berdasarkan hasil penelitian dapat disimpulkan bahwa pemberian ransum dengan level konsentrat $0,5 \mathrm{~kg}$ dan $1,0 \mathrm{~kg}$ menunjukkan bahwa tingkat pemberian konsentrat berpengaruh nyata terhadap kecernaan bahan kering dan kecernaan bahan organik sedangkan berpengaruh tidak nyata terhadap kecernaan protein kasar dan kecernaan serat kasar.

\section{Saran}

Saran yang dapat diberikan dari penelitian ini yaitu perlu dilakukan penelitian lebih lanjut untuk mengetahui berapa persen penambahan konsentrat yang optimum pada ransum agar mendapatkan kecernaan bahan kering (KCBK), kecernaan bahan organik (KCBO), kecernaan protein kasar (KCPK), dan kecernaan serat kasar (KCSK) tertinggi.

\section{UCAPAN TERIMA KASIH}

Penulis mengucapkan terima kasih kepada Rektor Universitas Udayana Prof. Dr. dr. A. A. Raka Sudewi, Sp.S (K) dan Dekan Fakultas Peternakan Universitas Udayana Dr. Ir. I Nyoman Tirta Ariana, MS yang telah memberikan kesempatan dan fasilitas kepada penulis selama menjalani perkuliahan di Fakultas Peternakan, Universitas Udayana. 


\section{DAFTAR PUSTAKA}

Anggorodi, R. 1994. Ilmu Makanan Ternak dasar. Gramedia, Pustaka Utama. Jakarta.

AOAC. 2005. Association of Official Agricultural Chemist. Published by the Association of Official Analytical Chemist. Maryland, USA.

Despal. 2000. Kemampuan komposisi kimia dan kecernaan in vitro dalam mengestimasi kecernaan in vivo. Media Peternakan 23 (3): 84 - 88.

Guntoro, S. 2006. Membudidayakan Sapi Bali. Penerbit Kanisius, Yogyakarta.

Hartutik. 2009. Strategi manajemen pemberian pakan dalam upaya peningkatan produktivitas sapi perah rakyat. Pidato Pengukuhan Guru Besar. Malang (Indonesia): Universitas Brawijaya.

Ismail, R. 2011. Kecernaan in vitro, http://rismanismail2.wordpress.com/2011/05/22/nilaikecernaan-part-4/\#more-310. (Rabu, 13 Februari 2020).

Ketellars, J. J and B. J. Tolkamp. 1992. Toward a new theory of feed intake regulation in ruminants. 1. Causes of differences in voluntary feed intake: critique of current views. Livestock Prod. Sci. 30:269-296.

Koddang, M. Y. A. 2008. Pengaruh tingkat pemberian konsentrat terhadap daya cerna bahan kering dan protein kasar ransum pada sapi bali jantan yang mendapatkan rumput raja (Pennisetum purpurephoides) ad-libitum. J. Agroland. 15 (4): 343-348.

Mariani, N. P., T. I. Putri, dan N. M. A. Rasna. 2019. Pengaruh Pemberian Konsentrat Pada Ransum Sapi Bali Induk Pasca Melahirkan. Laporan Penelitian Unggulan Udayana.

Maryono, 2006. Teknologi Inovasi "Pakan Murah" untuk Usaha Pembibitan Sapi Potong Lokal. Sinar Tani ed. 18 - 24 Oktober.

Maynard, L. A, J. K. Loosil, H. F. Hintz, and R. G Warner. 2005. Animal Nutrition. $7^{\text {th }}$ Edition McGraw-Hill Book Company. New York, USA.

McDonald, P., R. A. Edwards, J. F. D. Greenhalgh, and C. A. Morgan. 2002. Animal Nutrition. $7^{\text {th }}$ Edition Pearson Education Limited. Harlow.

Mukminah, N., N. Luthfi, A.P. Nugroho, E. Purbowati, E. Rianto, dan A. Purnomoadi. 2011. Kecernaan Protein dan Energi Pakan pada Kerbau Jantan yang Diberi Pakan Konsentrat dengan Frekuensi Pemberian yang Berbeda. Seminar Nasional Teknologi Peternakan dan Veteriner Hal: 153 - 157. 
Muladno. 2012. Aplikasi Teknologi Perbibitan untuk Peningkatan Produksi Bakalan dan Kualitas Daging Sapi Nasional. Proc. Seminar Nasional Peningkatan Produksi dan Kualitas Daging Sapi Bali Nasional. Bali, 14 September 2012.

Prasetiyono, B. W. H. E. ,Suryahadi, T. Toharmat, dan R. Syarief. 2007. Strategi suplementasi protein ransum sapi potong berbasis jerami dan dedak padi. Media Peternakan 30 (3): 207 - 217.

Priyono. 2009. Pencernaan Pakan pada Ternak Ruminansia. Ilmu Ternak Universitas Diponegoro. Semarang.

Sanh, M. V., H. Wiktorsson, dan L. V. Ly. 2002. Effects of natural grass forage to concentrate ratios and feeding principles on milk production and performance of crossbred lactating cows. Asian-Australian Journal Animal Science 15 (5): 650 - 657.

Setyaningsih W. Budiarti C, dan Suparyogi TH. 2013. Peran massage dan pakan terhadap produksi dan kadar lemak susu kambing Peranakan Ettawah. Anim Agric. 2:329-335.

Simon, P., Ginting A., Tarigan, dan R. Krisnan. 2011. Konsumsi fermentasi rumen dan metabolit darah kambing sedang tumbuh yang diberi silase i. arrecta dalam pakan komplit. Jurnal Ilmu Ternak Veteriner 17 (1): 49 - 58.

Steel, C. J. dan J. H. Torrie.1993. Prinsip dan Prosedur Statistik. PT. Gramedia. Jakarta.

Sudirman,2013. Evaluasi Pakan Tropis dari Konsep ke Aplikasi (Metode in- vitro Feces). Penerbit Pustaka Reka Cipta: Bandung.

Tillman, A. D., H. Hartadi, S. Reksohadiprodjo, S. Prawirokusumo, dan S. Lebdosoekojo, 1998. Ilmu Makanan Ternak Dasar. Gadjah Mada University Press. Yogyakarta.

Umiyasih, U. 2007. Petunjuk Teknis Ransum Seimbang Strategi Pakan pada Sapi Potong. Badan Penelitian dan Pengembangan Pertanian Departemen Pertanian. Jakarta.

Upeksa, I. G. N. D., N. N. Suryani, dan N. P. Sarini. 2016. Pengaruh pemberian level energi terhadap kecernaan nutrien ransum sapi bali bunting 7 bulan. Peternakan Tropika Vol. 4 (1): 196-207. Universitas Udayana.

Valentina, F. D., I W. Suarna, dan N. N. Suryani 2018. Kecernaan nutrien ransum dengan kandungan protein dan energi berbeda pada sapi bali dara. Peternakan Tropika 6 (1): 184-197. Universitas Udayana.

Winugroho, M., Suharyono, and Y. Widiawati. 2007. The effect of feeding Multi-nutrient Feed Supplement (MFS) and legor on PO cattle productivity. Proc. Seminar Nasional Teknologi Peternakan dan Veteriner. Bogor, 21-22 Agustus 2007 